\title{
Preparation of Bioglass/Chitosan Composite Incorporated with Dexamethasone by Sol-gel Method.
}

\author{
A. S. Abdraboh ${ }^{(a)}$, M. S. El-khooly ${ }^{*}$ (a) , and M. Y. Hassaan ${ }^{(b)}$. \\ (a)Biophysics Branch, ${ }^{(b)}$ Physics Department, Faculty of Science, Al-Azhar University, \\ Nasr City 11884, Cairo, Egypt
}

\begin{abstract}
TN THIS STUDY, we used the sol-gel method to prepare a composite of Bioglass/ chitosan doped with dexamethasone (Dexa) as an anti-inflammatory drug. A solution of 1 wt. $\%$ chitosan was prepared with $1 \%$ acetic acid (v/v), and was added to a mixture of tetraethyl orthosilicate (TEOS), triethyl phosphate (TEP)and Ca $\left(\mathrm{NO}_{3}\right)_{2} \cdot 4 \mathrm{H}_{2} \mathrm{O}$ as arrow materials of $\left(65 \% \mathrm{SiO}_{2}-25 \% \mathrm{CaO}-10 \% \mathrm{P}_{2} \mathrm{O}_{5}\right)$. Finally, different percentages of the drugs $(5,10,15$ wt. $\%)$ were added as follows BG/CH5D, BG/ $\mathrm{CH} 10 \mathrm{D}$ and $\mathrm{BG} / \mathrm{CH} 15 \mathrm{D}$ respectively. Thermal behavior and surface structure were investigated with different techniques. Bioactivity of all samples was determined after investigate in the simulate body fluid (SBF). Both the $\mathrm{pH}$ and the concentration of some ions such as calcium and phosphorus were measured. The results showed a layer of hydroxy apatite (HA) was deposited on the surface of all samples, but this layer decreased as the dexamethasone concentration increased due to cross-linking between the drug with $(\mathrm{BG} / \mathrm{CH})$ composite which confirms its biological activity despite carrying the drug used Dexa.
\end{abstract}

Keywords: Bioactive glass, Chitosan composite, Drug delivery system, Dexamethasone.

\section{INTRODUCTION}

Chitosan $(\mathrm{CH})$ has been extensively used in different biomedical applications, such as carrier of controlled drugs, in the manufacture of artificial membranes and orthopedic applications[1][3]. Chitosan based bone graft substitutes are biocompatible, biodegradable, osteo-inductive, osteo-conductive and structurally similar to bone, with excellent cost effectiveness and mechanical strength. Chitosan based hydrogels and wound healing bandages have also establish a great market in the field of medicine. More recently, chitosan has gained popularity for its use as a matrix molecule for drug delivery and also finds an upcoming utility in the area of dentistry[4]. Chitosan and its derivations have broad wide properties such as antibacterial, antimicrobial, coagulating, and drug delivery which have gained numerous attentions. Disadvantages of chitosan including weak mechanical properties, and low chemical and thermal stability[5]-[7].Polymers used in bioactive glass/polymer composites can improve the mechanical and physical properties of bioactive glasses and can also modify drug release profiles [3]. Hydroxyapatite (HA) can be chosen as biocompatibility symbol and its chemical composition is similar to the mineral part of bone and tooth tissue. Weak mechanical properties limit hydroxyapatite's application[8]. The main aim of this study was to prepare drug delivery system composed of bioactive glass/ chitosan composites loaded with different concentration of dexamethasone and evaluate bioactivity of different samples.

\section{Material and Methods}

We prepared and investigated the bioactivity of bioglass/chitosan biocomposite loaded with different concentration of dexamethasone. Where 
the first solution (A) of bioglass $\left(65 \% \mathrm{SiO}_{2}-\right.$ $25 \% \mathrm{CaO}-10 \% \mathrm{P}_{2} \mathrm{O}_{5}$ ) which prepared with solgel method was added to second solution (B)of chitosan polymer $1 \% \mathrm{wt}$. dissolved in $1 \%(\mathrm{v} / \mathrm{v})$ acidic acid. Dexamethasone with different concentrations $(5,10$ and $15 \%$ wt.) was added to the above $\mathrm{BG} / \mathrm{CH}$ composite $(\mathrm{A}+\mathrm{B})$. Bioactivity of samples were investigated with FTIR, TGA, DSC, SEM, and EDX before and after immersion in $(\mathrm{SBF}) . \mathrm{Ca}^{+2}, \mathrm{PO}_{4}^{-3}$ ions and $\mathrm{pH}$ was examined with UV-Vis spectroscopy after $(1,2,4,8,16,21$ and 33) days.

Preparation of bioglass / Chitosan solution.

A solution of bioactive glass was prepared with chemical Composition $65 \% \mathrm{SiO}_{2}, 10 \% \mathrm{P}_{2} \mathrm{O}_{5}$ and $25 \% \mathrm{CaO}$, for which tetraethyl orthosilicate
(TEOS; $\mathrm{Si}\left(\mathrm{OC}_{2} \mathrm{H}_{5}\right)_{4}$ (Assay 99.0\%) purchased from sigma aldrish Company, Canada) and triethyl phosphate (TEP; $\mathrm{C}_{6} \mathrm{H}_{15} \mathrm{O}_{4} \mathrm{P}$ (Assay 99.\% ${ }^{r}$ ) purchased from Alfa Aesar Company, Germany), and distilled water in ethanol (Merck). and $\mathrm{Ca}\left(\mathrm{NO}_{3}\right)_{2} \cdot 4 \mathrm{H}_{2} \mathrm{O}$ (Panreac PRS), were mixed as defined below: $24.43 \mathrm{ml}$ of TEOS was added into $4.22 \mathrm{~mL}$ of nitric acid $\left(\mathrm{HNO}_{3}\right)$ the mixture was allowed to react for 60 minutes to promote the acid hydrolysis of TEOS. Then, $2.38 \mathrm{ml}$ of $\mathrm{P}_{2} \mathrm{O}_{5}$ was added and mixed during 60 minutes, and finally, $10.74 \mathrm{gm}$ of $\mathrm{Ca}\left(\mathrm{NO}_{3}\right)_{2} \cdot 4 \mathrm{H}_{2} \mathrm{O}$ was added to the mixture and kept under stirring for 1.5 hour until hydrolysis perfected and polycondensation, following the protocol proposed by sol-gel method as shown in Fig. (1)[9].

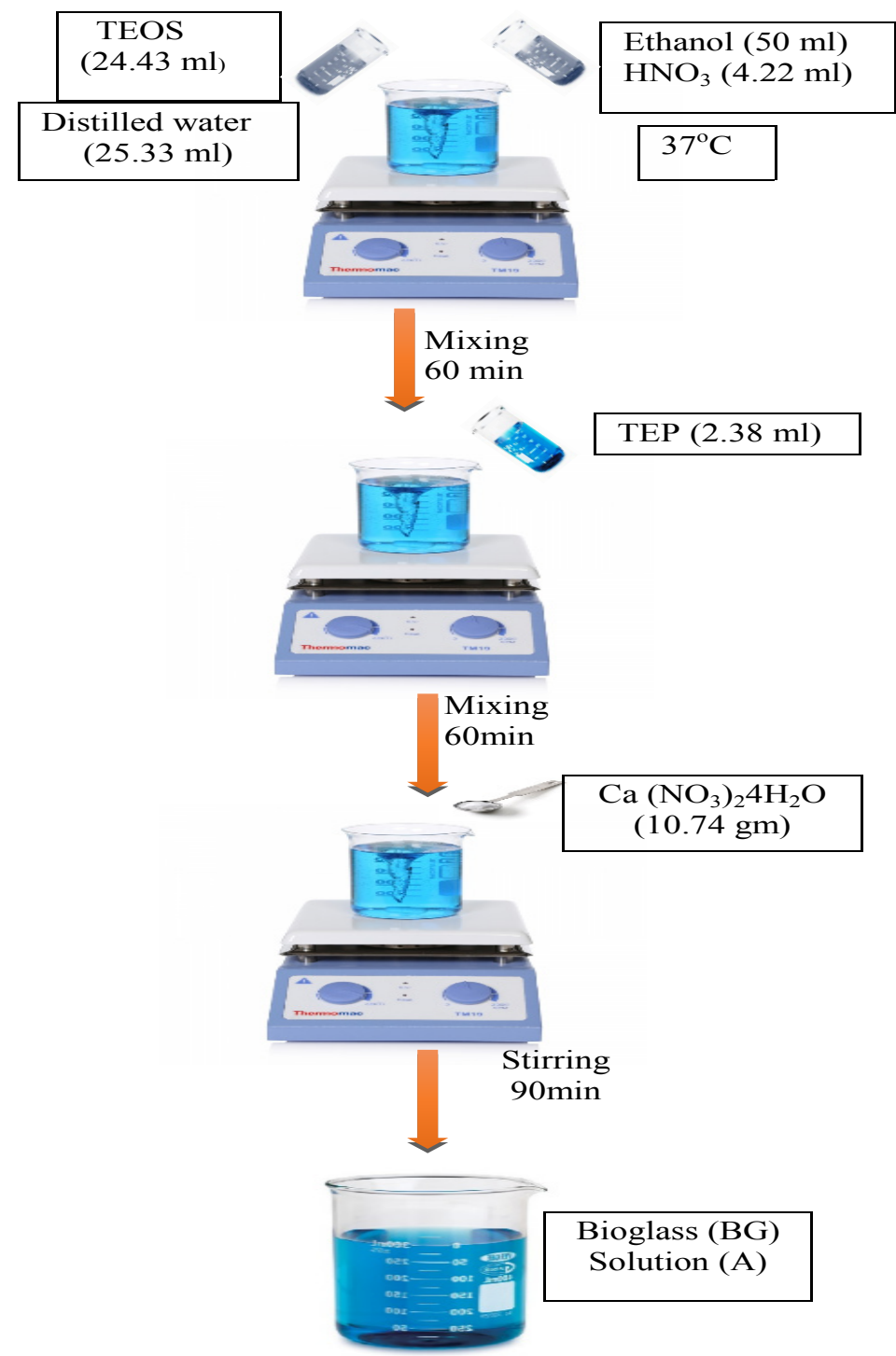

Fig.1. Flowchart for Bioglass preparation steps. 
Chitosan solution was prepared with a concentration of $1 \% \mathrm{wt} . / \mathrm{v}$, by dissolving $1 \mathrm{gm}$ of chitosan powder in a solution of $1 \%(\mathrm{v} / \mathrm{v})$ acetic acid with stirring during $3 \mathrm{~h}$. Then, TEOS/ $\mathrm{HNO}_{3}$, $\mathrm{P}_{2} \mathrm{O}_{5}$ and $\mathrm{Ca}\left(\mathrm{NO}_{3}\right)_{2} \cdot 4 \mathrm{H}_{2} \mathrm{O}$ as precursor compounds for bioactive glass production was added to the chitosan solution. The BG/CH precursor's solution was mixed thoroughly for 1.5 hour until fully homogenized. TEP as Crosslinking agent's solutions were prepared to be 1\% wt., seen in Fig. (2) [9].

Dexamethasone were found in Three samples with different wt. $\%$ of $(5,10$, and 15$)$ were added to solution of TEOS/HNO, $\mathrm{TEP}$, and $\mathrm{Ca}\left(\mathrm{NO}_{3}\right)$ as precursor of Bioglass. Subsequently added to a chitosan solution which prepared previously in 1 wt. $\%$ of acetic acid. The obtained mixture was stirred for 6 hours and dried for 2 days $/ 120^{\circ} \mathrm{C}$ as illustrated in Fig. (3).

The prepared composites loaded with dexamethasone are named according to dexamethasone concentration as $\mathrm{BG} / \mathrm{CH} 5 \mathrm{D}, \mathrm{BG} /$ $\mathrm{CH} 10 \mathrm{D}$, and BG/CH15D. All composites were examined with FTIR, SEM, EDX before and after invitro test in (SBF) and characterized with TGA, DSC. as well as calcium and phosphorous ions were evaluated in (SBF) after $(1,2,4,8,16,21$ and 33) days with UV-Vis spectroscopy.

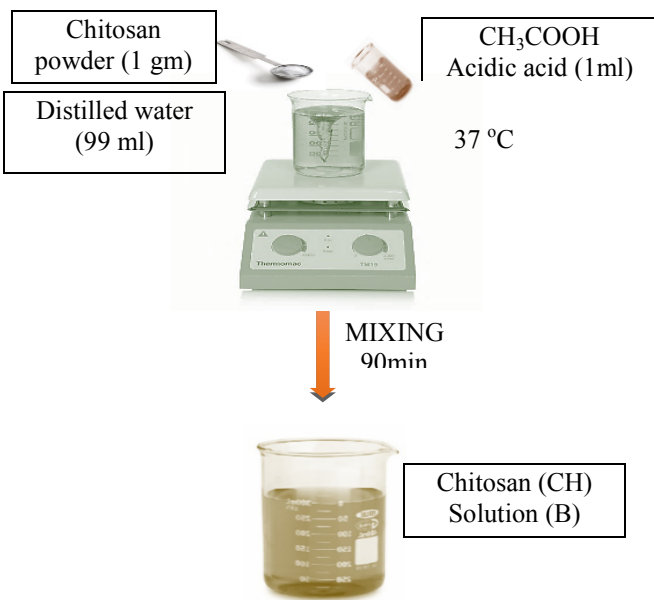

Fig.2. Flowchart for Chitosan preparation steps.

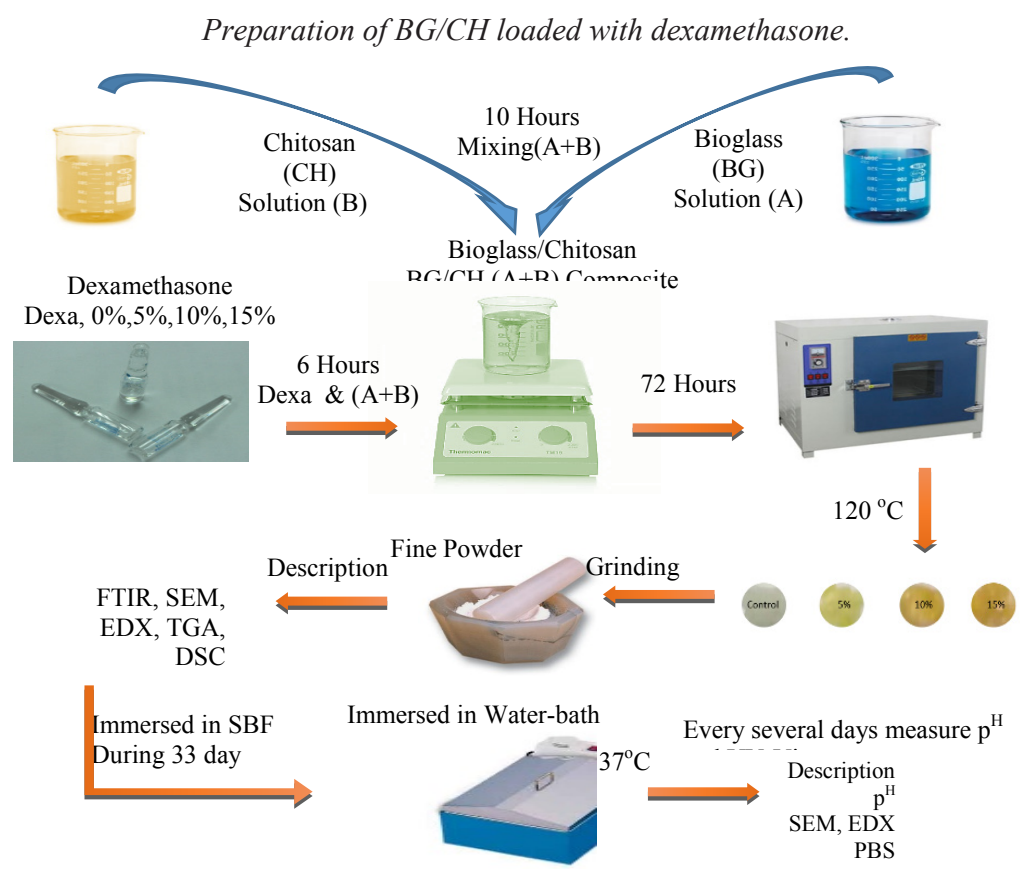

Fig.3. Flowchart for preparation of the BG/CH composite with dexamethasone loaded and investigate steps. 


\section{Standard Operating Procedure of (SBF) preparation.}

$0.5 \mathrm{~g}$ of each $\mathrm{BG} / \mathrm{CH}$ composite and $\mathrm{BG} / \mathrm{CH}$ with dexamethasone was immersed in $50 \mathrm{ml}$ of (SBF) with ion concentrations nearly equal to those of human blood plasma Table (1) under fixed conditions at $37^{\circ} \mathrm{C}$ for 33 days, in order to get a homogeneous apatite layer. SBF solution was prepared by adding concentrated solutions of $\mathrm{KCl}$, $\mathrm{NaCl}, \mathrm{NaHCO}_{3}, \mathrm{MgSO}_{4} \cdot 7 \mathrm{H}_{2} \mathrm{O}$ and $\mathrm{KH}_{2} \mathrm{PO}_{4}$ to distilled water buffered with tris(hydroxymethyl) aminomethane and $\mathrm{HCl}$ to $\mathrm{pH} 7.4$ at $37^{\circ} \mathrm{C}$ [10].

\section{Characterization techniques:}

Thermo Gravimetric Analysis (TGA) / Differential Scanning Calorimeter (DSC)

Thermogravimetric analysis of the various BG/CH dexamethasone in a SETARAM DTA-

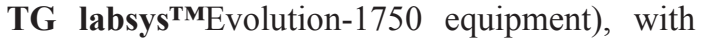
$\alpha-\mathrm{Al}_{2} \mathrm{O}_{3}$ powders as a reference material. Samples of $5 \mathrm{mg}$ crushed powder were put into an $\mathrm{Al}_{2} \mathrm{O}_{3}$ crucible and the measurements were performed in the temperature range $23-1000^{\circ} \mathrm{C}$ (heating rate $10{ }^{\circ} \mathrm{C} / \mathrm{min}$ ) in air. The data was baseline corrected by carrying out a blank run and subtracting this from the plot obtained instrument. The sample was heated in flowing Argon gas atmosphere at a heating rate of $10^{\circ} \mathrm{C} / \mathrm{min}$. The weight loss measurements were also done in the same instrument and both the graphs were merged into one for comparative analysis. The surface morphology of the resultant composite before and after immersion in SBF, was performed by using Philips XL 30 scanning electron microscope (SEM), with an accelerating voltage of $30 \mathrm{kV}$. Specimens were placed on a stub using a carbon sticker and examined under the microscope.

A $2 \mathrm{ml}$ sample of SBF is taken from each test tube after 1, 2, 4, 8, 16, 21 and 33 days from the beginning of the immersion. And stored frozen until analyzed for determining the concentration of $\mathrm{Ca}, \mathrm{P}$ and dexamethasone release as a drug concentration increase by a time by using UV-VIS spectroscopy (JASCO v-630).

The dissolution (Cation release) of Bioglass (BG), bioglass/chitosan $(\mathrm{BG} / \mathrm{CH})$ and various ratio of $(\mathrm{BG} / \mathrm{CH})$ dexamethasone were tested by soaking in $50 \mathrm{ml}$ of (SBF). The specimens within plastic containers were immersed in a thermodynamic (shaking-water bath at constant separate then incubated for 33 days at $37^{\circ} \mathrm{C}$ ). All the test materials were present in triplicate. Thus, there were altogether 3 test tubes for each material. The $\mathrm{pH}$ of the SBF solution was measured using Jenway $3510 \mathrm{pH}$ meter. The change in $\mathrm{pH}$ of the SBF with and without the modified by dexamethasone was recorded at predetermined time intervals.

\section{Results and Discussion}

Thermo Gravimetric Analysis (TGA)

The knowledge of the thermal behavior of organic-inorganic materials is of great importance, in determining their best processing conditions. Thermo gravimetric analysis (TGA) is an important tool for thermal stability studies of materials. It allows determining the temperature range at which a heated sample undergoes a major conformational change by means of monitoring the thermal weight loss profile.

TGA analysis was employed in the evaluation of the thermal stability of Bioglass/chitosan Composite that obtained by sol-gel process (10 ${ }^{\circ} \mathrm{C} / \mathrm{min}$ in nitrogen atmosphere).

Fig. (4): Shows TGA curves $\left(25-1000{ }^{\circ} \mathrm{C}\right.$ temperature range) of $\mathrm{BG} / \mathrm{CH}$ composite as a function of TEOS content. In order to follow some significant effects, the weight loss was studied in three temperature intervals: $0-147^{\circ} \mathrm{C}(\mathrm{I}), 148$ $235^{\circ} \mathrm{C}$ (II), $236-555^{\circ} \mathrm{C}$ (III).

The initial weight loss (Region I), in Bioglass/Chitosan and bioglass/Chitosan with dexamethasone is considered to be the result of the elimination of ethanol and water [11]. The weight loss in $\mathrm{BG} / \mathrm{CH}$ sample occurs at 50 up to $148^{\circ} \mathrm{C}(31.14 \%$ weight loss), whereas in the BG/ $\mathrm{CH}$ with dexamethasone, this loss starts from $50^{\circ} \mathrm{C}$ to $148^{\circ} \mathrm{C}$. The quantity of water and ethanol that lost from the samples are losing, increases with the decreasing of dexamethasone ratio. This result agree with more tendency to hydrolysis with decreasing dexamethasone content.

TABLE 1. Comparison of the ionic concentrations in blood plasma and the theoretical one in SBF $\left(\mathrm{mmol} \mathrm{l}^{-1}\right)$.

\begin{tabular}{ccccccccc}
\hline & $\mathbf{N a}^{+}$ & $\mathbf{K}^{+}$ & $\mathbf{M g}^{2+}$ & $\mathbf{C a}^{2+}$ & $\mathbf{C l}^{-}$ & $\mathbf{H C O}_{3}^{-}$ & $\mathbf{H P O}_{4}{ }^{2-}$ & $\mathbf{S O}_{4}{ }^{2-}$ \\
\hline Bloodplasma & 142.0 & $3.6-5.5$ & 1.0 & $2.1-2.6$ & $95.0-107.0$ & 27.0 & $0.65-1.45$ & 1.0 \\
SBF & 142.0 & 5.0 & 1.0 & 2.5 & 126.0 & 10.0 & 1.0 & 1.0 \\
\hline
\end{tabular}

Egypt. J. Biophys. Biomed. Eng., Vol. 20 (2019) 


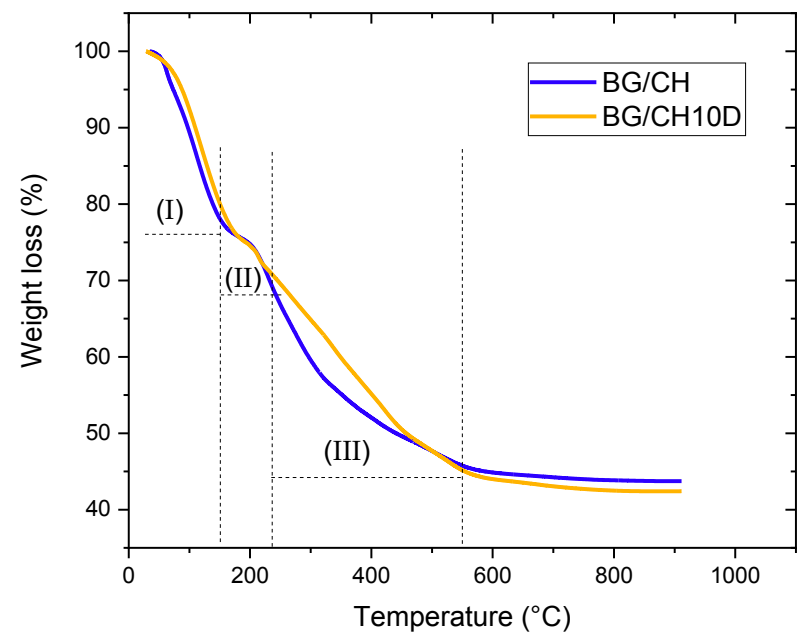

Fig. 4. TGA curves of $\mathrm{BG} / \mathrm{CH}$ and $\mathrm{BG} / \mathrm{CH} 10 \mathrm{D}$ samples.

The second weight loss (Region II), is due to the partial thermal degradation of organic matter (The Chitosan) in the BG/CH composite. The elimination of organic matter in $\mathrm{BG} / \mathrm{CH}$ sample occurs from 148 up to $235{ }^{\circ} \mathrm{C}$ with $(8.5 \%$ weight loss), whereas in the Bioglass/chitosan with dexamethasone, this loss starts from $145{ }^{\circ} \mathrm{C}$ to $235{ }^{\circ} \mathrm{C}$. The elimination of organic components from the hybrids start at $150{ }^{\circ} \mathrm{C}$, this indicates that, in order to avoid the elimination of organics from the samples, the composite should be cured while being prepared at a temperature which does not exceeds $150{ }^{\circ} \mathrm{C}$. In other words, $120{ }^{\circ} \mathrm{C}$ is a suitable temperature for curing these hybrids[12], [13].

The third weight loss stage (Region III) at 236$555^{\circ} \mathrm{C}(23.5 \%$ weight loss $)$ is due to the complete burning of organics in the hybrid [14]. The TGA curves became flat at $600-1000^{\circ} \mathrm{C}$ because the organic component had been completely removed, leaving behind only an inorganic component as $\mathrm{SiO}_{2}$ and $\mathrm{Ca}\left(\mathrm{NO}_{3}\right)_{2} \cdot 4 \mathrm{H}_{2} \mathrm{O}$.

From the TGA data, it is clear that, as the hydrocarbon chain content increases, the weight loss increase. In addition, $120^{\circ} \mathrm{C}$ is a suitable temperature for curing these hybrids.

Differential Scanning Calorimeter (DSC).

It is important to study the structure of bioactive glasses to understand its properties. Many of the physical properties, such as the crystallization temperature and solubility are intimately related to the alkali metals content and to their contribution in the structure.
Thus, a better knowledge of the structural role of the alkali metal components in particular will lead to an improved understanding of the relationship between structure and properties. So that, thermal analysis was performed on the synthesized Bioglass/Chitosan $(\mathrm{BG} / \mathrm{CH})$ composite and $\mathrm{BG} /$ $\mathrm{CH}$ composite with dexamethasone (BG/CH10D) to find out the major phenomena occur during sintering. DSC trace is a plot of heat changes of the composite as a function of temperature and used to determine temperatures at which phase transitions occur.

Fig. (5) shows that the DSC trace exhibited two endothermic peaks and three exothermic peaks for the two samples.

The first broad endothermic peak, which initiated nearly at room temperature to reach at $135^{\circ} \mathrm{C}$ and $149^{\circ} \mathrm{C}$ for $\mathrm{BG} / \mathrm{CH}$ and $\mathrm{BG} / \mathrm{CH} 10 \mathrm{D}$ respectively, consistent with the consumption of heat energy to release the physisorbed water and the pore liquor (water and alcohol by-products from the polycondensation reaction) that were not removed during drying[15]. The observed endothermic peaks in the range of $85-149^{\circ} \mathrm{C}$ is attributed to the loss of the residual solvent (water and ethanol)[16]. All the DSC curves show endothermic peaks in the range of temperature of 50 to $149^{\circ} \mathrm{C}$. The presence of such peaks was attributed to the loss of volatile components or the possibility of chain relaxation. Furthermore, in this temperature range is also verified the breakdown of hydrogen bonds which are present in chitosan structure and other molecular associations [17]. 
TABLE 2. Thermogravimetric Results Obtained fof Bioglass / Chitosan Free and Dexamethasone

\begin{tabular}{|c|c|c|}
\hline \multicolumn{3}{|c|}{ TGA } \\
\hline Sample & Weight loss $\%$ at $600{ }^{\circ} \mathrm{C}$ & Residue $50 \%$ at ${ }^{\circ} \mathrm{C}$ \\
\hline $\mathrm{BG} / \mathrm{CH}$ & 65.2 & 440.9 \\
\hline BG/CH10D & 65.01 & 457.5 \\
\hline
\end{tabular}

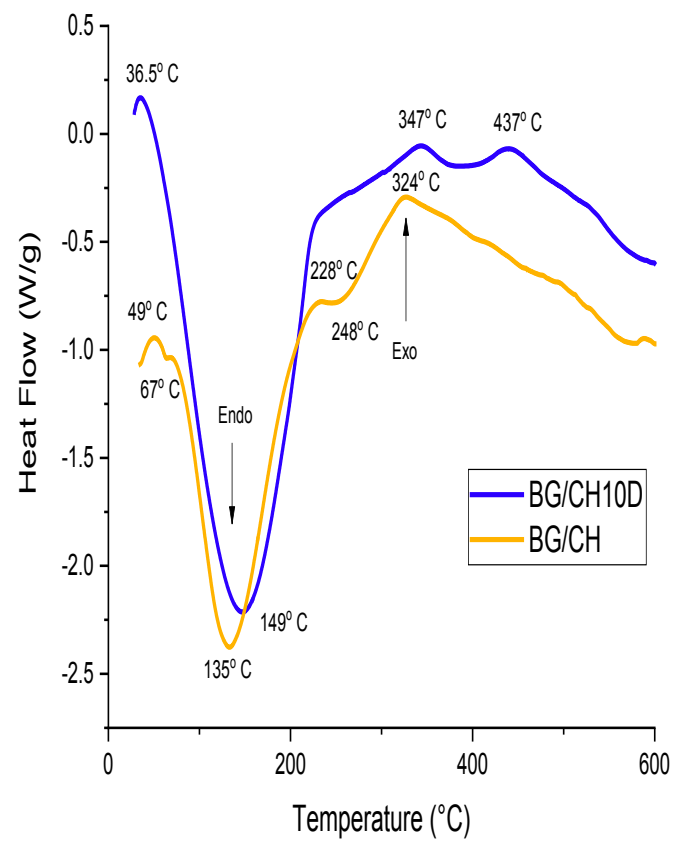

Fig. 5. DSC thermo analysis curves of $B G / C H$ and $B G / C H 10 D$ samples.

The second endothermic peak, observed at $248^{\circ} \mathrm{C}$ corresponds to the pyrolysis reaction of free organic species (ethoxy group) and/or the release of the resulting water from the two reactions: the first is the further condensation of silanol groups ( $\mathrm{Si}$---O--- $\mathrm{Si})$ between $(\mathrm{Si}---\mathrm{OH})$ and $(\mathrm{OH}---\mathrm{Si})$, the second is also condensation of phosphate group (P---O---P) between $(\mathrm{P}---\mathrm{OH})$ and $(\mathrm{OH}--$ -P) [18]. This silanol group of the colloidal silica gel is thought to be changed to $\mathrm{SiO}_{2}$ via two steps like the evaporation of water and ethanol and the decomposition of organic residues like $\mathrm{SiO}-\mathrm{C}_{2} \mathrm{H}_{5}$ derived from the freest reactions of silica gel network surfaces with ethanol solvent [19].

The exothermic peaks, curve of pure Bioglass/ Chitosan exhibits a weak exothermic peak at $324^{\circ} \mathrm{C}$, which is attributed to the degradation of that Chitosan and the curve of BG/CH10D with dexamethasone there is another peak appeared at $347^{\circ} \mathrm{C}$ to collapse the chemical bond between the $\mathrm{BG} / \mathrm{CH}$ and dexamethasone.
Two exothermic peaks are also observed at 347 and $437^{\circ} \mathrm{C}$ related to the thermal decomposition for amine and acetyl residues, characteristic for BG/CH10D sample [20].

\section{Biological Protein adsorption}

The chemical composition and surface charge of biomaterial surfaces strongly affect the protein adsorption behavior[21]. This is perhaps through interaction between the functional groups on the samples surfaces and those of the protein itself. After immersion of the samples in $10 \mathrm{mg} / \mathrm{ml}$ Bovine Serum albumin solution in PBS, adsorption was allowed to proceed in an incubator for $2 \mathrm{~h}$ at $37^{\circ} \mathrm{C}$.

Fig. (6) shows spectral decomposition of amide I band and amide II band for Bovine Serum Albumin (BSA) adsorption through the surfaces of samples, (a) $\beta$-sheet at $1680 \mathrm{~cm}-1$, (b) $\alpha$-helix at $1653 \mathrm{~cm}-1$, (c) $\beta$ - sheet at $1627 \mathrm{~cm}-1$, (d) $\beta$-sheet at $1555 \mathrm{~cm}-1$ (e) $\beta$-sheet and random at $1524 \mathrm{~cm}$ 1 , ( $\mathrm{a}, \mathrm{b}, \mathrm{c}$ peaks for amide I band, $\mathrm{d}$, e peaks for amide II band) [22]. 


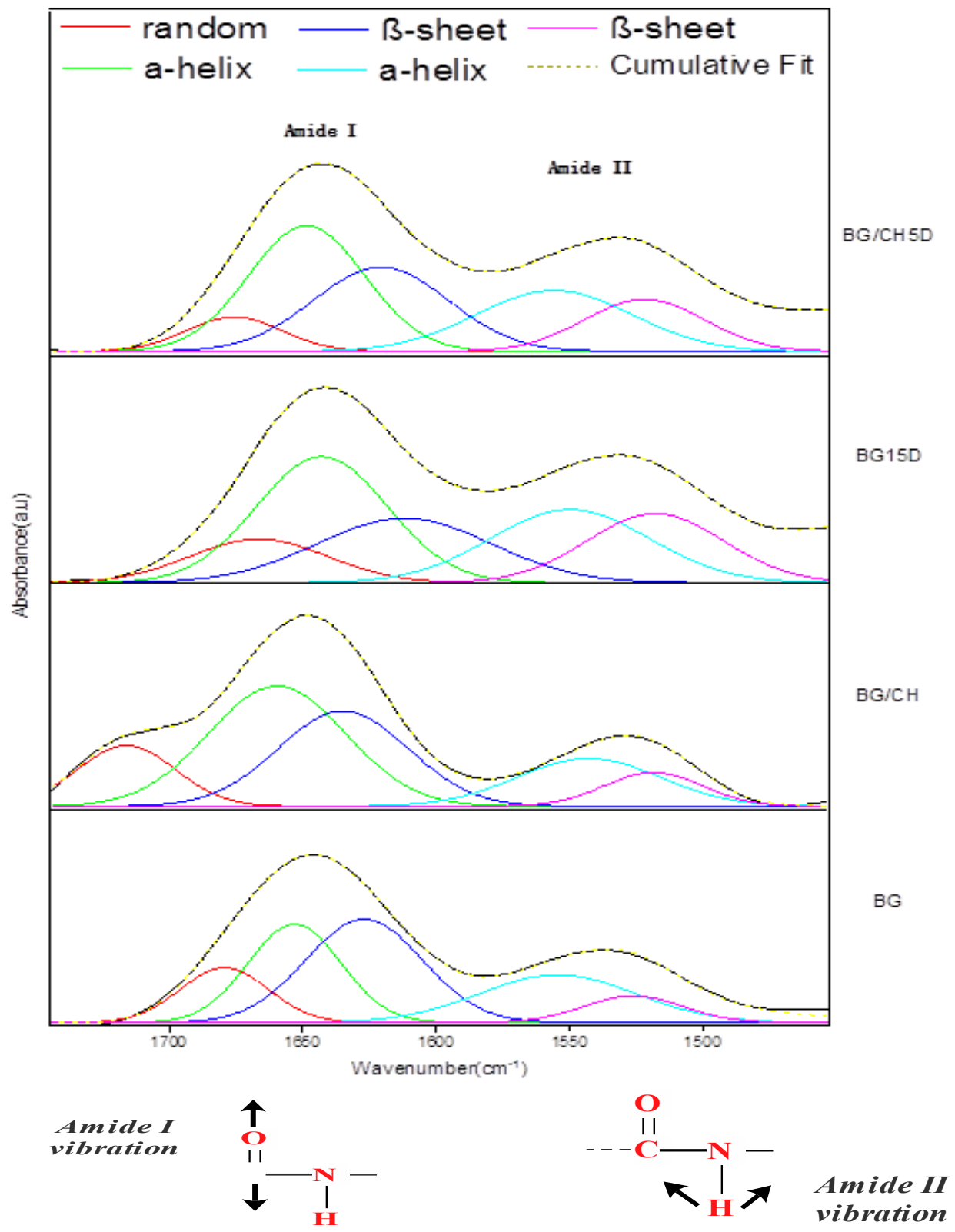

Fig. 6. FTIR spectra of the Amide I and Amide II bands of BSA adsorbed on the surfaces of the samples.

There was an increase in the ratio of the Amide I to the Amide II on all the surfaces of bioglass sample (BG) due to adsorption. According to the popularly accepted understanding, electrostatic interactions are very important for protein adsorption [23].

The ratio between Amide I and Amide II respectively increased in $\mathrm{BG}$ sample and decreased gradually in $\mathrm{BG} / \mathrm{CH} 5 \mathrm{D}, \mathrm{BG} / \mathrm{CH} 10 \mathrm{D}$ and $\mathrm{BG} / \mathrm{CH} 15 \mathrm{D}$ samples.

The increased of surface negativity of the
Bioglass (BG) due to the amount of hydroxyl group enhanced the reactivity of the BG indicating that strongly protein adsorption due to the interaction between the amine group $\mathrm{NH}_{2}$ of the bovine serum albumin (BSA) with the $\mathrm{OH}$ group of Bioglass surface and the interaction between Chitosan and Dexamethasone (Dexa) by nucleophilic addition reaction[24]. For Dexa immobilization, the amino groups of Chitosan surface were reacted with carbonyl groups of Dexa to form the DexaChitosan formation shown in Fig (7).

Egypt. J. Biophys. Biomed. Eng., Vol. 20 (2019) 


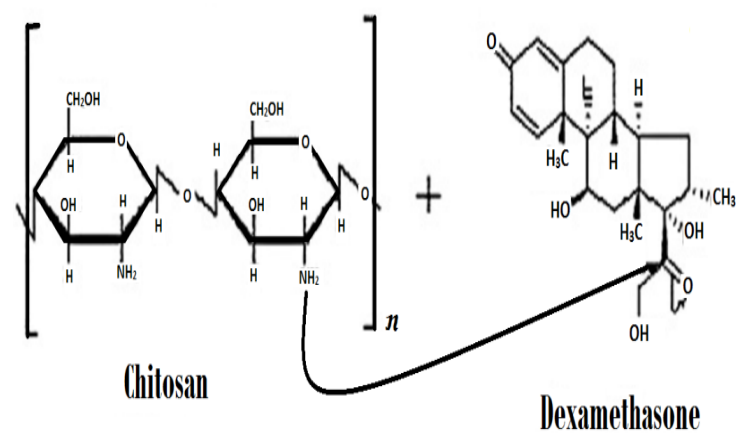

Fig. 7. Interaction between Chitosan and Dexamethasone [24].

Negativity of the surface of $\mathrm{BG} / \mathrm{CH}$ and $\mathrm{BG} / \mathrm{CH}$ loaded with dexa decreased due to the reactivity with carbonyl group of dexamethasone with Bioglass and chitosan, which blocked the negative sites on the surface. From the results in Fig (4.11) it can be concluded that the reactivity of protein with $\mathrm{BG} / \mathrm{CH} 5 \mathrm{D}, \mathrm{BG} /$ CH10D and BG/CH15D decreased gradually due to decreasing of negativity of the surface, which decreased by interaction with carbonyl group of Dexamethasone.

\section{Morphological analysis of samples (SEM \& $E D X)$.}

Dexamethasone does not seem to produce detectable changes in the morphology of the polymeric matrix. Also, from EDX analysis results, the presence of $\mathrm{Si}, \mathrm{Ca}$ and $\mathrm{P}$ indicating that BG was conducted to chitosan matrix. The bonebonding capability of a composite is determined by its ability to formation of apatite layer on its surface upon immersion in SBF solution for (33 day), a part from some exception where as it is possible to a material to be directly bonded to living bone without the formation of apatite on their surface [25].

The EDX data reveals that the silicon (Si) ions in the composite surface showed slightly decreasing after 33 days in SBF, followed by an increase in calcium (Ca) and phosphorous (P). The increases in $\mathrm{Ca}$ and $\mathrm{P}$, accompanied by a decrease in the concentration of Si on the surface of the composite sample, prove the development of apatite. As it is observed in EDX spectra of samples after immersion along 33 days in SBF [26].Also, the association of chitosan with bioactive glass improved the formation and the crystallization of hydroxyapatite layer.
It is considered that the porous structure of $\mathrm{BG} / \mathrm{CH}$ biocomposite microsphere should be responsible for the formation of a dense apatite layer. From the EDX analysis results, the presence of $\mathrm{Si}, \mathrm{Ca}$ and $\mathrm{P}$ indicating that $\mathrm{BG}$ was conducted to chitosan matrix and on the surface of composite it can be demonstrated, as shown in Fig (8).

The $\mathrm{BG} / \mathrm{CH}$ biocomposite with a high surface area to volume can facilitate the transport of $\mathrm{Ca}^{2+}$ and $\mathrm{PO}_{4}^{3-}$ ions from the physiological fluid onto the surface of $\mathrm{BG} / \mathrm{CH}$ biocomposite to form a dense apatite layer. These porosity of BG/ $\mathrm{CH}$ deceased as dexamethasone concentrations increased in $\mathrm{BG} / \mathrm{CH} 10 \mathrm{D}$ and $\mathrm{BG} / \mathrm{CH} 15 \mathrm{D}$ than $\mathrm{BG} / \mathrm{CH} 5 \mathrm{D}$, which decrease the formation of apatite layer shown in Fig (9).

\section{Calcium concentration}

The change in concentration of $\mathrm{Ca}$ ions can reflect the competition condition between the rate of dissolution and precipitation processes. At first, the concentration of calcium in SBF solution is approximately $100 \mathrm{mg} / \mathrm{l}$. The Ca concentration was found to be increase more than $100 \mathrm{mg} / \mathrm{l}$ this means that the dissolution rate is faster than the precipitation rate, while the $\mathrm{Ca}$ concentrations showed values less than $100 \mathrm{mg} / \mathrm{l}$.

Fig (10) shows the change of concentration of $\mathrm{Ca}$ ions after soaking of $\mathrm{BG} / \mathrm{CH}$ loaded with Dexamethasone in SBF solution. The increase in the $\mathrm{Ca}$ concentration observed for all specimens from the first day up to the eight day in SBF is attributed to dissolution of the bioglass phase. The rate of dissolution started to be gradually decreased from day 8 up to 33 days of immersed in SBF. 

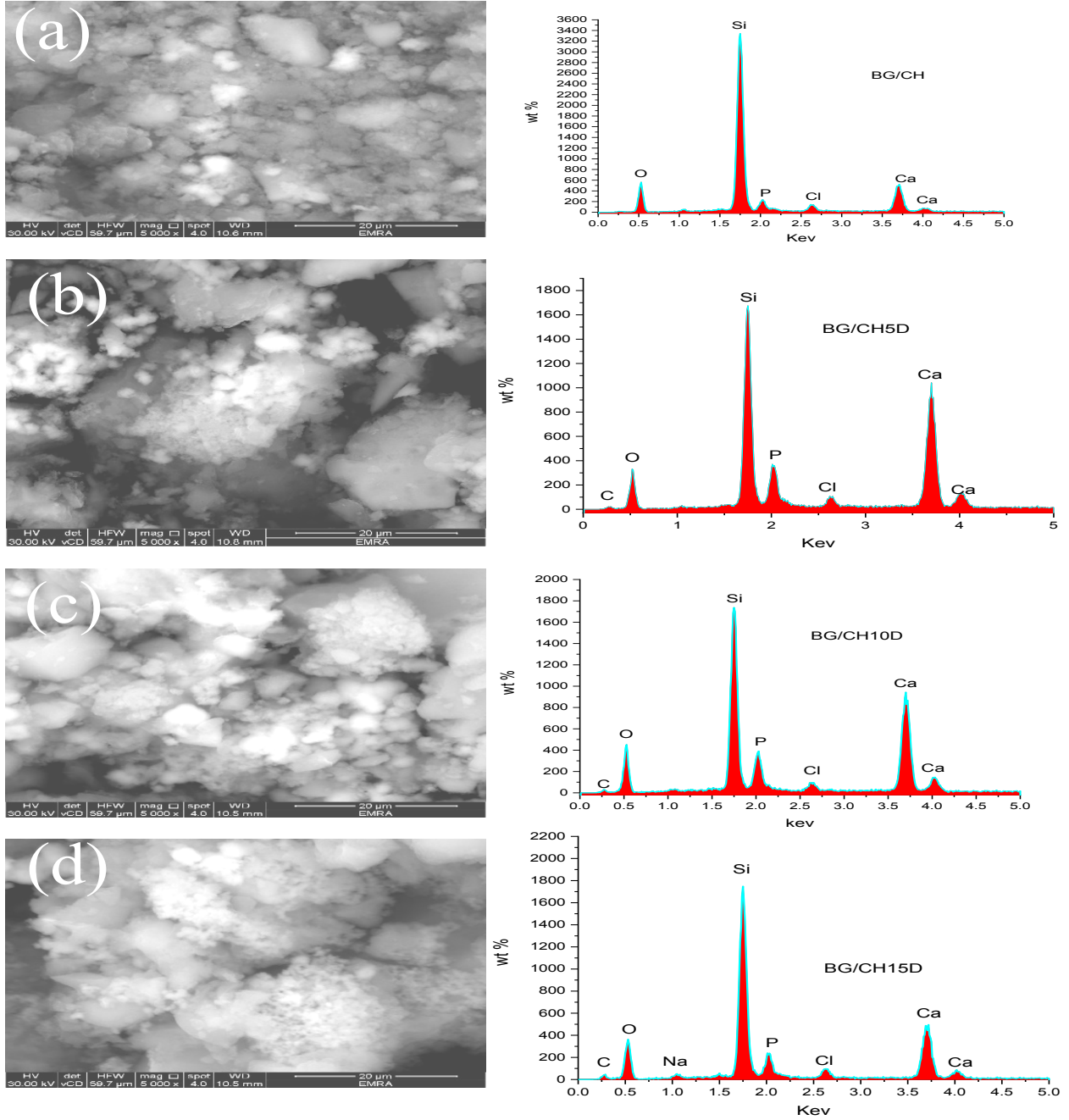

Fig. 8. SEM image - EDX spectrum of (a) BG/CH (b) BG/CH5 (c) BG/CH10D (d) BG/CH15D after immersion in SBF for 33 days.

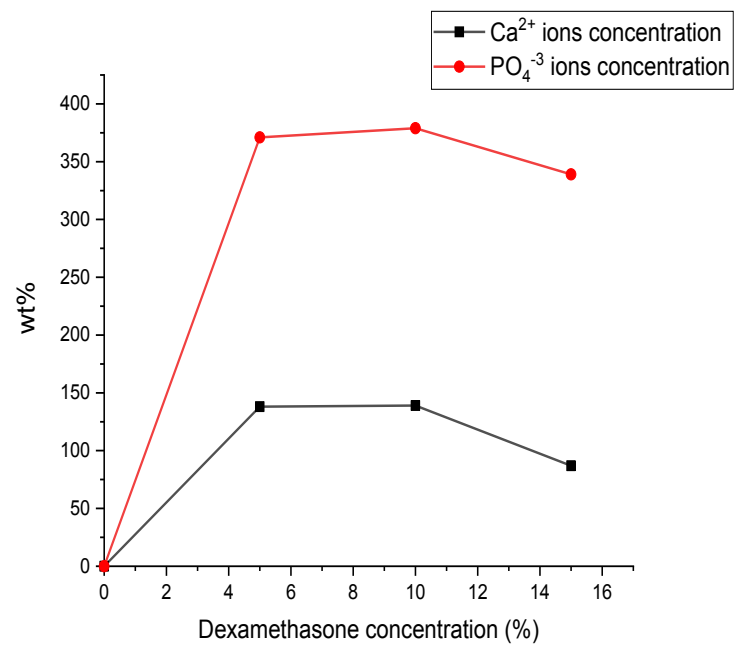

Fig. 9. Release profile of dexamethasone in terms of the percentage (\%) as a function of Ca and P concentration. 


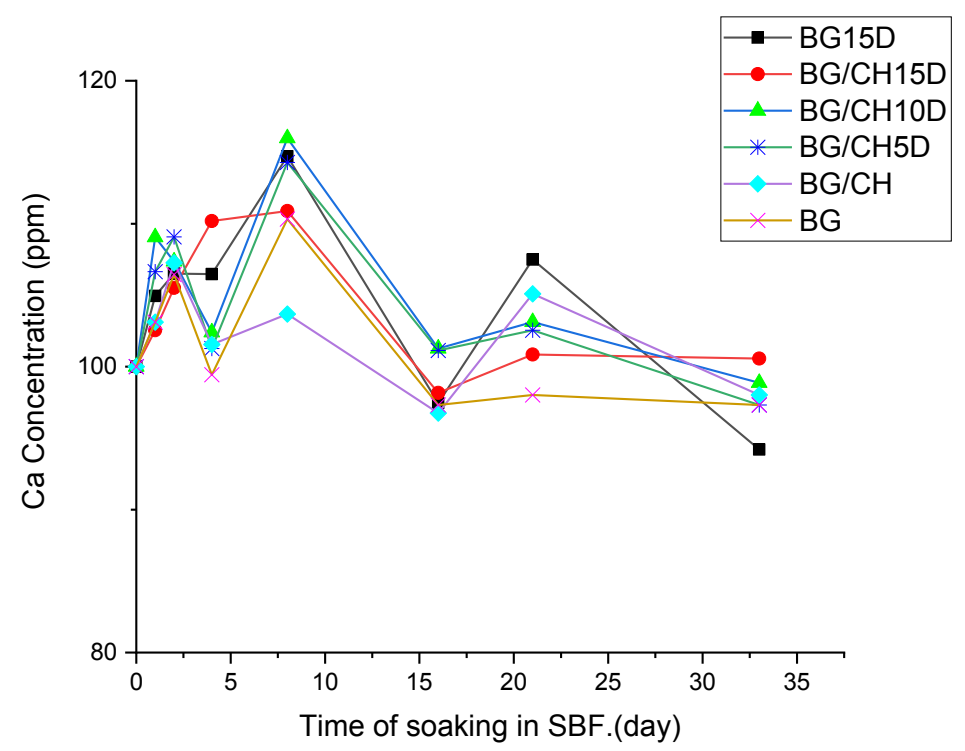

Fig. 10. The concentration of Ca2+ ions after soaking in SBF solution for 33 days.

The calcium concentration seems to increase at the initial stage for all the $\mathrm{BG} / \mathrm{CH}$ composites. This increase in calcium concentration is induced by the release of calcium ions from the $\mathrm{BG} / \mathrm{CH}$ composites. The decrease of calcium concentration from 8 up to 33 days may be due to the consumption of calcium ions through apatite formation on their surfaces[27].

The decreasing in the $\mathrm{Ca}^{2+}$ ions concentration in SBF is attributed to the rapid growth of the apatite nuclei formed on the surface of the BG/ $\mathrm{CH}$ composite that overcome the release rate of calcium ions to the solution. The $\mathrm{pH}$ varied according to $\mathrm{Ca}^{2+}$ concentration variations, because of $\mathrm{Ca}^{2+}$ ions in the $\mathrm{BG} / \mathrm{CH}$ composite exchanged with $\mathrm{H}^{+}$or $\mathrm{H}_{3} \mathrm{O}^{+}$in the $\mathrm{SBF}$ [28]. This means that a layer of apatite formed in all samples, but the surface area of it decreased by increasing the dexamethasone concentration.

\section{Phosphorus concentration}

Fig (11) shows the concentration of $\mathrm{P}^{5+}$ ions after 33 days soaking of the composites in SBF solution. Before immersion phosphate ion concentration in SBF is $30 \mathrm{ppm}$ only. After immersion of the samples in SBF for 33days, at $24 \mathrm{~h}$ it is noted that phosphate concentration in all $\mathrm{BG} / \mathrm{CH}$ composites increased up to high values due to release of phosphate from these samples to the solution, but it was gradually decreased after $24 \mathrm{~h}$ up to the fourth day to reach low values indicating the consumption of phosphate in the

Egypt. J. Biophys. Biomed. Eng., Vol. 20 (2019) formation the layer of crystalline HCA on the surface of $\mathrm{BG} / \mathrm{CH}$ composites.

After soaking in SBF phosphorus concentration increased rapidly from 4 up to 10 days, then it showed approximately a constant value from 10 up to 33 days. This decrease in phosphorus concentration maybe due to the consumption of phosphate ions through the formation of apatite on the surfaces of $\mathrm{BG} / \mathrm{CH}$ composites with chitosan and dexamethasone [29].

pH analysis

The variation of $\mathrm{pH}$ values relative to soaking time in $\mathrm{SBF}$ of $\mathrm{BG} / \mathrm{CH}$ and $\mathrm{BG} /$ Dexa composites are shown in Fig (12) The dissolution of $\mathrm{Ca}^{2+}$ ions from the samples maybe lead to the locally increase of the $\mathrm{pH}$ value of the surrounding fluid. In the start and during the four days, $\mathrm{pH}$ decreased until reach a value of 7.420 Bioglass (BG), 7.383 (BG15D), $7.302(\mathrm{BG} / \mathrm{CH}), 7.316$ (BG/CH5D), 7.405 (BG/CH10D) and $7.392(\mathrm{BG} / \mathrm{CH} 15 \mathrm{D})$.

The $\mathrm{pH}$ increased after 4 to 16 days in SBF immersed as a consequence of partial dissolution that gives an idea about the high reactivity of these materials. These facts agree with the formation mechanisms of the apatite layer on $\mathrm{BG} / \mathrm{CH}$ composite, i.e., in early stages, an interchange takes place between $\mathrm{Ca}^{2+}$ and $\mathrm{H}_{3} \mathrm{O}^{+}$ions from the solution. Such interchanges provoke an increase in $\mathrm{pH}$ that accordingly favors the formation of apatite nuclei on the silanol groups in the $\mathrm{BG} / \mathrm{CH}$ composites surface. 


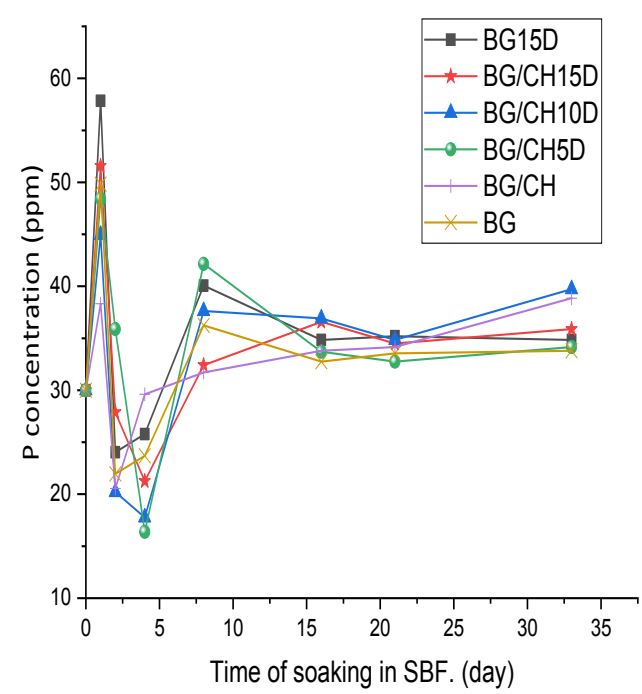

Fig. 11. The concentration of $\mathrm{P}^{5+}$ ions in SBF solution after soaking for 33 days.

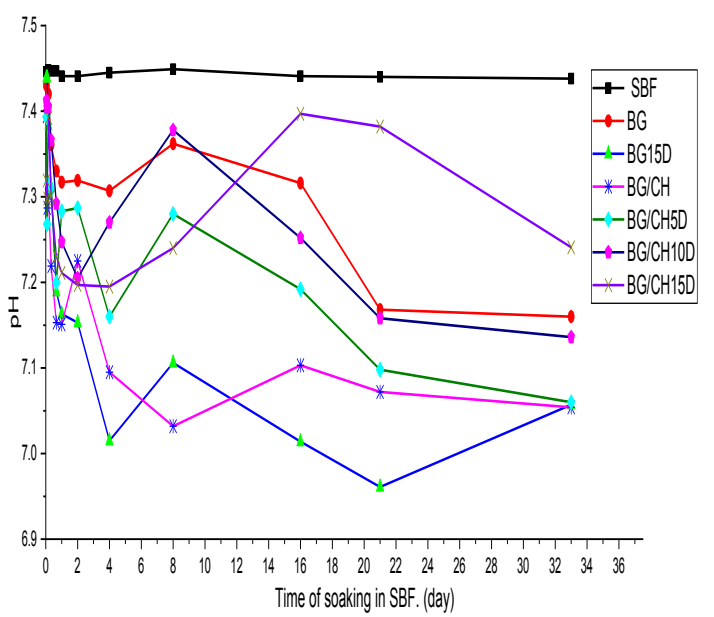

Fig. 12. The change in $\mathrm{pH}$ results of $\mathrm{BG}, \mathrm{BG} / \mathrm{CH}$ and $\mathrm{BG} / \mathrm{CH}$ loaded with Dexamethasone after immersion in SBF for 33days.

The formation of apatite in SBF is strongly $\mathrm{pH}$ dependent; the increase in $\mathrm{pH}$ actually signifies for the reduction in the concentration of $\mathrm{H}+$ due to the replacement of metal ions in the $\mathrm{BG} / \mathrm{CH}$ composites and subsequent production of $\mathrm{OH}-$ groups due to breaking of siloxane bond. [30]

From the 16 day up to 33-days of immersion in SBF the $\mathrm{pH}$ decreased gradually until reach 7.16 Bioglass (BG), 7.057 (BG15D), 7.054 (BG/ $\mathrm{CH}), 7.06$ (BG/CH5D), 7.136 (BG/CH10D) and 7.241 (BG/CH15D). The fluctuation in $\mathrm{pH}$ values of all samples may be explained when considering the result of two opposite processes:

i. The release of $\mathrm{Ca}^{2+}$ from the $\mathrm{BG} / \mathrm{CH}$ composites.

ii. The consumption of $\mathrm{Ca}^{2+}$ due to the formation of apatite layer.
Therefore, when the releasing rate of $\mathrm{Ca}^{2+}$ is higher than its consumption rate, the $\mathrm{pH}$ will be changed ether by increase or decrease.

It is found from the results that substitution of $\mathrm{Ca}$ ions in the $\mathrm{BG} / \mathrm{CH}$ composites increase the solubility of the $\mathrm{BG} / \mathrm{CH}$ composites, which subsequently increase the interchange $\mathrm{Ca}^{2+}$ and $\mathrm{H}_{3} \mathrm{O}^{+}$ions from the solution and increase the $\mathrm{pH}$ value.

The $\mathrm{pH}$ changes within the body can be used to induce a response since different organs or tissues have different and specific $\mathrm{pH}$ value. Table (3) shows the different $\mathrm{pH}$ of some organs or tissues within the human body. The presence of ionizable weak

Egypt. J. Biophys. Biomed. Eng., Vol. 20 (2019) 
TABLE 3. pH in the different tissues (adapted from [31])

\begin{tabular}{lc}
\hline Tissue/ organ & pH \\
\hline Blood & $7.35-7.45$ \\
Stomach & $1.0-3.0$ \\
Duodenum & $4.8-8.2$ \\
Colon & $7.0-7.5$ \\
Early endosome & $6.0-6.5$ \\
Late endosone & $5.0-6.0$ \\
Lysosome & $4.5-5.0$ \\
Tumor & $6.5-7.2$ \\
\hline
\end{tabular}

\section{Conclusion}

- Bioactive glass/Chitosan Composite incorporated with Dexamethasone was prepared with sol-gel method.

- Thermal behavior and surface structure were estimated with different techniques (TGA, DSC, SEM and EDX).

- Bioactivity of prepared samples were evaluated in vitro by simulated body fluid

- The results indicated that a layer of hydroxy apatite (HA) was formed on the surface of all samples, but this layer decreased as the dexamethasone concentration increased due to cross-linking between the drug with $(\mathrm{BG} /$ $\mathrm{CH})$ composite which confirms its biological activity despite carrying the drug used Dexa.

- Bioactive glass / chitosan composites is low cost and effective biomaterial.

In an upcoming study we will study the exit of the drug dexamethasone with ultraviolet light (UV-Vis spectroscopy) technique.

\section{References}

1. W. J. E. M. Habraken, J. G. C. Wolke, and J. A. Jansen, "Ceramic composites as matrices and scaffolds for drug delivery in tissue engineering," Adv. Drug Deliv. Rev., vol. 59, no. 4-5, pp. 234-248, 2007.

2. M. E. Gomes and R. L. Reis, "Biodegradable polymers and composites in biomedical applications : from catgut to tissue engineering Part 1 Available systems and their properties," vol. 49, no. 5, pp. 261-273, 2004.

3. A. J. Domb, Focal Controlled Drug Delivery. 2014.

4. M. N. V. R. Kumar, R. A. A. Muzzarelli, C. Muzzarelli, H. Sashiwa, and A. J. Domb, "Chitosan chemistry and pharmaceutical perspectives," Chem. Rev., vol. 104, no. 12, pp. 6017-6084, 2004.
5. H. Aydın, Ç. Yerlikaya, and S. Uzan, "Equilibrium and kinetic studies of copper (II) ion uptake by modified wheat shells," Desalin. Water Treat., vol. 44, no. 1-3, pp. 296-305, 2012.

6. I. Genta, P. Perugini, B. Conti, and F. Pavanetto, "A multiple emulsion method to entrap a lipophilic compound into chitosan microspheres," Int. J. Pharm., vol. 152, no. 2, pp. 237-246, 1997.

7. D. Green, D. Walsh, X. Yang, S. Mann, and R. O. C. Oreffo, "Stimulation of human bone marrow stromal cells using growth factor encapsulated calcium carbonate porous microspheres," J. Mater. Chem., vol. 14, no. 14, pp. 2206-2212, 2004.

8. Eroglu H, Kas HS, Oner L, Turkoglu OF, Akalan N, Sargon MF, "The in-vitro and in-vivo characterization of PLGA:L-PLA microspheres containing dexamethasone sodium phosphate AU H. EROG LU, H. S. KASe, L. ONER, Oe . F. TUe RKOG LU, N. AKALAN, M. F. SARGON and N. Oe ZER," J. Microencapsul., vol. 18, no. 5, pp. 603-612, Jan. 2001.

9. J. J. Yoon, J. H. Kim, and T. G. Park, "Dexamethasone-releasing biodegradable polymer scaffolds fabricated by a gas-foaming/salt-leaching method," Biomaterials, vol. 24, no. 13, pp. 2323 2329, 2003.

10. D. M. Escobar-Sierra, J. S. Posada-Carvajal, and D. L. Atehortúa-Soto, "Fabrication of chitosan/ bioactive glass composite scaffolds for medical applications," Rev. Tec. la Fac. Ing. Univ. del Zulia, vol. 40, no. 4, pp. 30-36, 2017.

11. T. Kokubo and H. Takadama, "How useful is SBF in predicting in vivo bone bioactivity?," Biomaterials, vol. 27, no. 15, pp. 2907-2915, 2006.

12. V. C. Costa, H. S. Costa, and W. L. Vasconcelos, "Preparation of Hybrid Biomaterials for Bone Tissue Engineering," Mater. Res., vol. 10, no. 1, pp. 21-26, 2007. 
13. [13] Z. Zhou, J. Ruan, J. Zou, and Z. Zhou, "Preparation and bioactivity of sol-gel macroporous bioactive glass," vol. 15 , no. 3 , pp. 290-296, 2008.

14. [14] S. J. Castillo, M. A. E. Zayas, H. Arizpe, D. De Investigación, U. De Sonora, and A. Postal, "Formation of $\mathrm{ZnO}$ in or on glasses by using the Sol-Gel and Chemical Bath Deposition Techniques," vol. 9, no. 3, pp. 143-152, 2010.

15. [15] F. A. M. Abdul-rahman, I. T. M. Motawea, and E. A. Shoreibah, “AL-AZHAR,” 2017.

16. [16] A. R. C. Duarte, F. Mano, and R. L. Reis, "Dexamethasone-loaded scaffolds prepared by supercritical-assisted phase inversion," vol. 5, pp. 2054-2062, 2009.

17. [17] L. B. Rodrigues, H. F. Leite, M. I. Yoshida, J. B. Saliba, A. S. Cunha, and A. A. G. Faraco, "In vitro release and characterization of chitosan films as dexamethasone carrier," vol. 368, pp. 1-6, 2009.

18. [18] X. Bui, H. Oudadesse, Y. Le Gal, A. Mostafa, and G. Cathelineau, "Microspheres of ChitosanBioactive Glass for Application in Orthopedic Surgery . In vitro experiment," Recent Res. Mod. Med. Cambridge, United Kingdom, pp. 359-367, 2011.

19. [19] M. Catauro, A. Dell, and S. Vecchio, "Thermochimica Acta Synthesis, structural, spectroscopic and thermoanalytical study of sol gel derived $\mathrm{SiO} 2-\mathrm{CaO}-\mathrm{P} 2 \mathrm{O} 5$ gel and ceramic materials," Thermochim. Acta, vol. 625, pp. 20 27, 2016.

20. [20] H. Li, "Preparation and Characterization of Homogeneous Hydroxyapatite/Chitosan Composite Scaffolds via In-Situ Hydration," $J$. Biomater. Nanobiotechnol, vol. 01, no. 01, pp. 42-49, 2010.

21. M. Vallet-Regí, A. M. Romero, C. V. Ragel, and R. Z. LeGeros, "XRD, SEM-EDS, and FTIR studies of in vitro growth of an apatite-like layer on sol-gel glasses," J. Biomed. Mater. Res., vol. 44, no. 4, pp. 416-421, 1999.

22. B. R. Barrioni et al., "Evaluation of in vitro and in vivo biocompatibility and structure of cobaltreleasing sol-gel bioactive glass," Ceram. Int., vol. 44, no. 16, pp. 20337-20347, 2018.

23. J. Massera, "HAMASA FAQHIRI CHITOSAN AND SILICABIOACTIVE GLASS 3D POROUS," no. June, 2016.
24. R. S. C. M. D. Q. Antonino et al., "Preparation and characterization of chitosan obtained from shells of shrimp (Litopenaeus vannamei Boone)," Mar. Drugs, vol. 15, no. 5, pp. 1-12, 2017.

25. S. Talebian et al., "Chitosan (PEO)/bioactive glass hybrid nanofibers for bone tissue engineering," RSC Adv., vol. 4, no. 90, pp. 49144-49152, 2014.

[26] M. Ray, K. Pal, A. Anis, and A. K. Banthia, "Development and Characterization of Chitosan based Polymeric Hydrogel Membranes," vol. 13, no. 3, pp. 193-206, 2010.

[27] R. P. da Silva et al., "New Polymorph Form of Dexamethasone Acetate," J. Pharm. Sci., vol. 107, no. 2, pp. 672-681, 2018.

[28] B. Li et al., "Synthesis, Characterization, and Antibacterial Activity of Cross-Linked ChitosanGlutaraldehyde," Mar. Drugs, vol. 11, no. 5, pp. 1534-1552, 2013.

[29] J. Mota et al., "Chitosan/bioactive glass nanoparticle composite membranes for periodontal regeneration," Acta Biomater, vol. 8, no. 11, pp. 4173-4180, 2012.

[30] M. Forteza, E. Galán, and J. Cornejo, "Interaction of dexamethasone and montmorillonite - Adsorption-degradation process," Appl. Clay Sci., vol. 4, no. 5-6, pp. 437-448, 1989.

[31] C. Gandhimathi, "Controlled Release of Dexamethasone in PCL/Silk Fibroin/Ascorbic Acid Nanoparticles for the Initiation of Adipose Derived Stem Cells into Osteogenesis," J. Drug Metab. Toxicol., vol. 06, no. 02, 2015.

[32] Z. C. Chiang, S. H. Yu, A. C. Chao, and G. C. Dong, "Preparation and characterization of dexamethasone-immobilized chitosan scaffold," $J$. Biosci. Bioeng., vol. 113, no. 5, pp. 654-660, 2012.

(Recieved 24/6/2019; accepted 3/8/2019)

Egypt. J. Biophys. Biomed. Eng., Vol. 20 (2019) 


\section{إعداد مزيج من الزجاج الحيوي والكيتوزان المحضر بطريقة السول جل مدمج معه \\ احمد صابر عبدربه , محمد صلاح حسن الخولي , محمد يسري محمد انور حسان

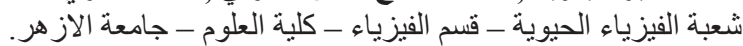

يتألف العظم من هجين من مواد عضوية مثل الباف الكو لاجين وغير عضوية مثل مادة الهيدروكسى اباتيت. لذلك و احدة من السمات المهمة و المطلوبة في تصميم بدائل العظام النشطة النّا

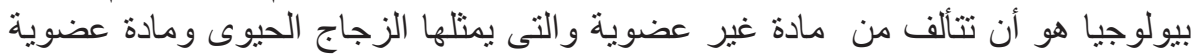

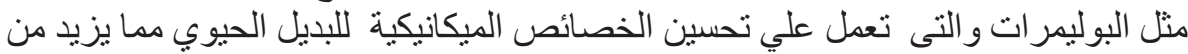
مرونتها بجانب أنها نشطة حيو يا وبالتالي تكون أفضل من السير اميك الحيوي.

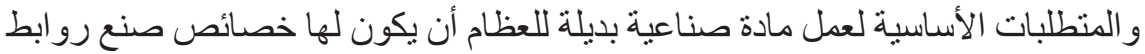

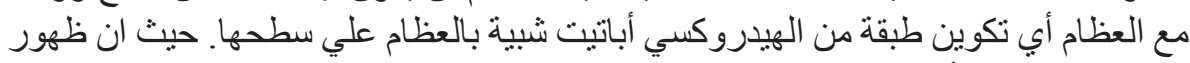

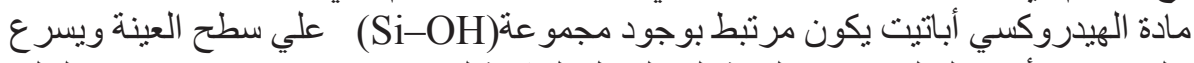

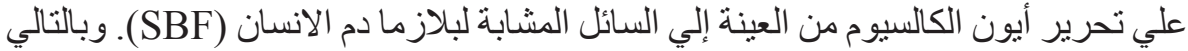

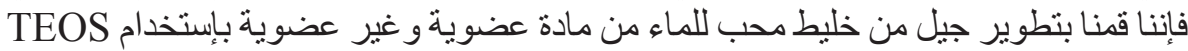

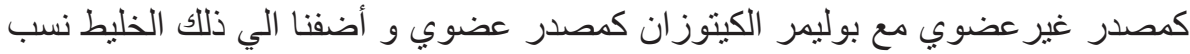
مختلفة من عقار مضاد الالتهابات (Dexamethasone) .تم في هذه الدر استة تحضبر العينات كالتالى :

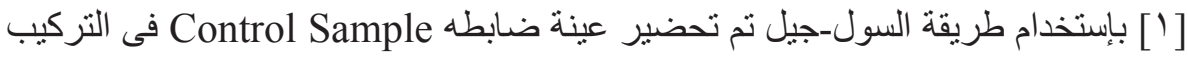

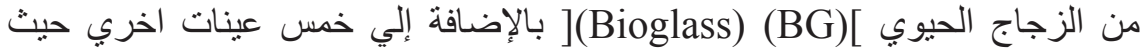

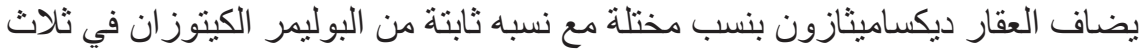

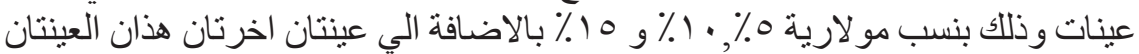

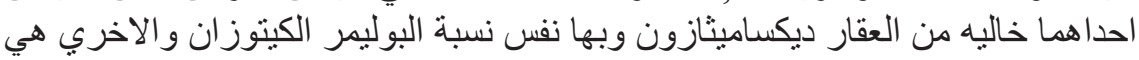

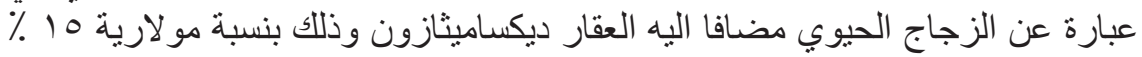
ولكن بدون البوليمر الكيتوزان واسمائهم كما يلي./BG/CH, BG/CH5D, BG) CH10D, BG/CH15D) هذا لفهم التفاعل بين العقار والزجاج الحيوي ومعرفة الي اي منهم كانت تنتمي المركبات

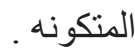

[ץ] تم التخلص من الرطوبة و الايثانول الموجود بالعينات التى تم تحضير ها وذلك بالمعالجها

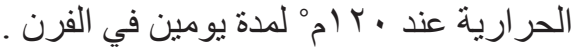

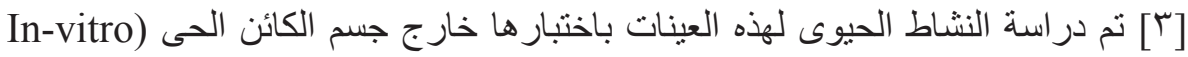

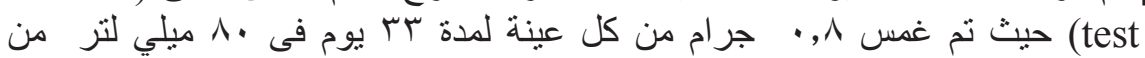

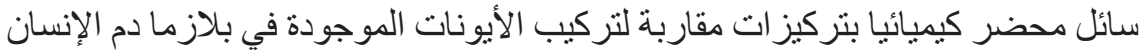

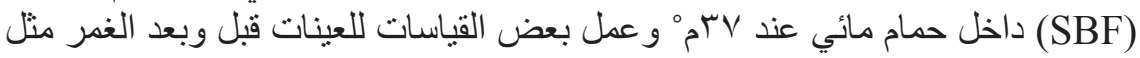

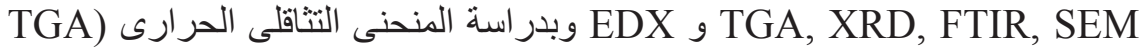

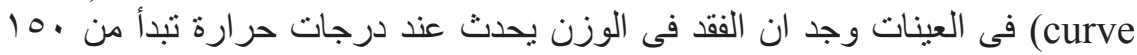

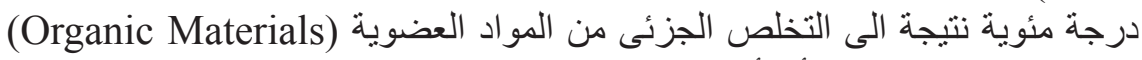

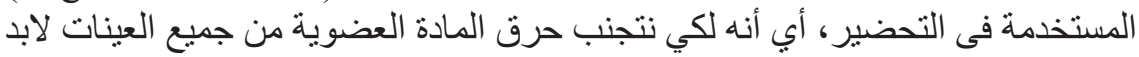

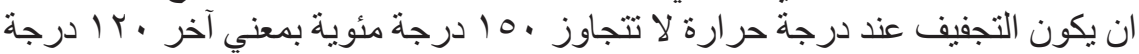
مئوية هي درجة حر ارة مناسبة لتجفيف العينات في الفرن. 